\title{
A Role for Ethylene in the Yellowing of Broccoli after Harvest
}

\author{
M.S. Tian', C.G. Downs, R.E. Lill, and G.A. King \\ New Zealand Institute for Crop and Food Research, Levin Research Center, Private Bag 4005, Levin, \\ New Zealand
}

Additional index words. 1-aminocyclopropane-1-carboxylic acid (ACC), ACC oxidase, Brassica oleracea, chlorophyll, degreening, ethylene production, hue angle, propylene, respiration rate, senescence, tissue sensitivity

\begin{abstract}
Ethylene production from florets of 'Shogun' harvested broccoli (Brassica oleracea L.var. italica) held at 20C in darkness increased as the sepal tissues yellowed. The pattern of respiration rate and ethylene production from branchlets or entire heads was similar, although the magnitude of ethylene and carbon dioxide production appeared to be diluted by the other fleshy stem tissues. The reproductive structures, stamens and pistil, may have a role in determining the rate of sepal degreening, since removing them from florets reduced the yellowing rate. The pistil and stamens also had 7-fold higher levels of 1-aminocyclopropane-1-carboxylic acid (ACC) oxidase activity and more than double the ethylene production of other tissues within the floret. Stamen ACC oxidase activity was high on the first day after harvest, before yellowing became obvious. Changes in ACC oxidase activity of the pistil and stamens mirrored changes in ACC content in these tissues. The climacteric status of harvested broccoli was confirmed by exposure to $0.5 \%$ propylene. Propylene stimulated respiration and ethylene production and accelerated yellowing (measured as chlorophyll and hue-angle decline). Broccoli tissues did not respond to propylene immediately after harvest. In tissues aged in air before treatment, the time for response to propylene was shorter, a result suggesting a change in tissue sensitivity. Ethylene exposure induced a dose-dependent decline in hue angle, with 1 ppm ethylene giving the maximum response.
\end{abstract}

Broccoli is a compact, rapidly developing floral vegetable that is usually harvested when the flowering heads are immature and growing rapidly. When harvested, the floral apices are separated from nutrients, hormones, and energy supplied by the roots and leaves. Consequently, broccoli florets senesce rapidly as is typical of commodities harvested before physical growth has ceased (Huber, 1987).

The most obvious feature of broccoli postharvest senescence is sepal degreening due to chlorophyll degradation (Wang, 1977). It has been proposed that ethylene has an important role in this chlorophyll loss (Aharoni et al., 1985; Watada, 1986). Some broccoli cultivars show a climacteric pattern of respiration and ethylene production (Makhlouf et al., 1989, 1991; Rushing, 1990), with increased ethylene and carbon dioxide production associated with tissue degreening. Ethylene biosynthetic inhibitors, such as aminoethoxyvinylglycine acid (AVG) and inhibitors of ethylene action (silver ions) delay chlorophyll loss in broccoli (Aharoni et al., 1985; Wang, 1977). However, it is unclear whether yellowing is regulated by postharvest changes in endogenous ethylene production or by changes in the floral tissues' sensitivity to ethylene.

A change in a tissue's sensitivity to a phytohormone may be induced by a change in concentration of the phytohormone, a change in the quantity or quality of the receptor(s), a change in the affinity of the phytohormone for its receptor, or any combination of these factors (Firn, 1986). This work describes the sensitivity of broccoli floret tissues to ethylene or its analogue propylene and changes in sensitivity after harvest. The term sensitivity is used to describe the response of broccoli tissues to exogenous ethylene or propylene.

In other floral systems, in particular carnation, ethylene has a

Received for publication 29 Apr. 1993. Accepted for publication 13 July 1993. We thank J. Heyes for discussion and D. Legg for technical assistance during this research. The cost of publishing this paper was defrayed in part by the payment of page charges. Under postal regulations, this paper therefore must be hereby marked advertisement solely to indicate this fact.

'To whom reprint requests should be addressed. critical role in regulating senescence processes (Nichols, 1977; Nichols et al., 1983; Woodson, 1987). In carnation it seems that ethylene or aminocyclopropane-1-carboxylic acid (ACC), a transmissible substrate in ethylene synthesis produced in the reproductive structures, influences petal senescence (Nichols, 1977). A similar mechanism has recently been proposed for cymbidium orchid (Woodson, 1987). To determine whether endogenous ethylene production plays a similar role in sepal yellowing in broccoli, we examined ethylene synthesis, ACC content, and ACC oxidase activity within the components of broccoli florets at $0,1,2$, and 3 days after harvest.

\section{Materials and Methods}

'Shogun' broccoli seedlings with four leaves were planted in individual 8-1iter plastic bags in a medium containing Fibremix (a bark-based growing medium), $40 \mathrm{~g}$ dolomite lime, $16 \mathrm{~g}$ superphosphate, $3.2 \mathrm{~g}$ fritted trace elements (FTE255), $0.4 \mathrm{~g}$ iron chelate, and $24 \mathrm{~g}$ osmocote (3 to 4 months). During winter, the plants were grown in a glasshouse under natural light, with temperature controlled at 20/15C day and night, respectively. During summer, plants were grown in a shadehouse without temperature control. At maturity, whole potted plants were equilibrated at $20 \mathrm{C}$ for $12 \mathrm{~h}$ in darkness before being sampled for experiments. During the experiments, all broccoli tissues were maintained at $20 \mathrm{C}$ in darkness.

In this work, a whole head refers to the entire infloresence harvested from one plant. The term stalk refers to a subunit of the head, comprising a 5-mm stem on which 200 to 300 individual florets are borne.

Winter-grown plants were used for measuring respiration and ethylene production from whole heads and branchlets, tissue sensitivity to ethylene and propylene, and sepal chlorophyll after the removal of reproductive structures. For experiments monitoring respiration, ethylene production, ACC oxidase activity, and ACC content of florets, plants grown during the summer were used.

A sterilized blade was used to cut heads $(\approx 200 \mathrm{~g})$ with a $70-\mathrm{mm}$ 
stem from plants. The heads were then surface-sterilized with $0.01 \%(\mathrm{w} / \mathrm{v}) \mathrm{NaOCl}$ solution for $2 \mathrm{~min}$ before two rinses with distilled water. Branchlets were prepared in a similar fashion.

Color and chlorophyll measurement. The color (as hue angle) was measured at three points midway between the outside and center of heads or branchlets using a chromometer (model CR-200; Minolta, Japan) fitted with CIE illuminant C and an 8-mm measuring aperture.

Measurement of chlorophyll content was based on the Moran and Porath method (1980). Florets $(300 \mathrm{mg})$, trimmed from whole heads or those already detached, were immersed in $6 \mathrm{ml}$ $\mathrm{N}, \mathrm{N}$-dimethylformamide and stored at $4 \mathrm{C}$ in the dark for $24 \mathrm{~h}$ before spectrophotometric examination. In most cases three or five floret samples from each treatment were analyzed.

Respiration and ethylene measurement. Each broccoli head was placed immediately after harvest in a 3-1iter plastic barrier film bag through which humidified ethylene-free air $\left(15 \mathrm{ml} \cdot \mathrm{min}^{-1}\right)$ was passed. Alternatively, three branchlets were placed in each of five 600-ml containers through which humidified ethylene-free air flowed $\left(9 \mathrm{ml} \cdot \mathrm{min}^{-1}\right)$. Ethylene and carbon dioxide produced by heads and branchlets were measured from 1-ml samples withdrawn from the output tube of the air flow systems at 0, 5, 8, 12, 24, 36, 48, and $72 \mathrm{~h}$ after harvest. Five individual heads and 15 branchlets were analyzed for each treatment.

Ethylene was analyzed on a gas-liquid chromatograph (GLC) (Shimadzu, Kyoto, Japan) fitted with a column (Porapak N, 80/100 mesh; Alltech, USA) and a flame-ionization detector. Carbon dioxide was analyzed with a GLC (Pye Unicam, Cambridge, England) fitted with a column (CTR 1; Alltech, USA) and a thermal-conductivity detector.

Ethylene and propylene treatment. Systems like those described above were used to measure ethylene production and respiration rate of heads or branchlets after exposure to an airflow $\left(9 \mathrm{ml} \cdot \mathrm{min}^{-1}\right)$ containing $0.5 \%$ propylene. All gases were humidified and the containers were stored in darkness at 20C for up to 72 h. In these experiments, 5 heads, or 15 branchlets per treatment, were analyzed.

In the experiment in which branchlets were held in air for 0,1 , 2 , or 3 days before treatment with propylene, 15 branchlets of each treatment per day were enclosed in five containers (three branchlets/ container) through which air (control) or $0.5 \%$ propylene flowed. They were analyzed for hue angle at $0,12,24,36$, and $48 \mathrm{~h}$ after each treatment started.

For the measurement of color change in response to different ethylene concentrations, five branchlets were sealed into each of six 1100-ml containers (one container at each ethylene concentration). One gram of carbon dioxide absorber (soda lime, 3-9 mesh) was placed in each container. Purafil (Papworth Engineering, New Zealand) (10 g), a commercial ethylene scrubber based on potassium permanganate, was placed in the control only. Various concentrations of ethylene $(0,0.01,0.1,1.0,10$, and $100 \mathrm{ppm})$ were established in each container and the oxygen concentration was maintained at higher than $18 \%$. Color (hue angle) of each stalk was measured after $36 \mathrm{~h}$.

Ethylene, ACC content, ACC oxidase, and chlorophyll in dissected florets. Sixty branchlets were held in ten 1100-ml containers (six branchlets/container) through which ethylene-free humidified air flowed. Fifteen branchlets per day were taken and dissected for measuring ethylene production and ACC oxidase activity. Samples for ACC analysis were immediately frozen in liquid $\mathrm{N}$, then stored at $-70 \mathrm{C}$.

Whole florets or the dissected parts of florets were incubated in three Petri dishes containing $15 \mathrm{ml} 0.4 \mathrm{~m}$ mannitol for $2 \mathrm{~h}$ at $20 \mathrm{C}$ in darkness. Sepals, petals, pistils, and stamens were obtained by gently teasing the floret open under a dissecting microscope, and the parts were removed with a sharp, sterilized scalpel. ACC oxidase activity (measured as ethylene synthesis) was measured after incubation in the medium containing $1 \mathrm{~mm} \mathrm{ACC} \mathrm{(Sigma)} \mathrm{and}$ 200 to $500 \mathrm{mg}$ fresh tissue weight sealed in 4-ml vials for $2 \mathrm{~h}$ more at $20 \mathrm{C}$ in darkness. Ethylene in a $100-\mu$ sample of the headspace gases was determined using a gas chromatograph (Photovac; Alltech, New Zealand) fitted with a XE-60 column (packed with $60 / 80$ carbopack B) and a photoionization detector. Analyses were performed in triplicate. ACC was extracted from three 200-mg samples per day of whole or dissected floret parts using 3 to $5 \mathrm{ml}$ $80 \%$ ethanol. After centrifugation $(5000 \times g$ for $15 \mathrm{~min}$ at $4 \mathrm{C})$, the supernatants were evaporated under vacuum at $50 \mathrm{C}$ and the residue was dissolved in $0.5 \mathrm{ml}$ water. The ACC assay used a 0.1$\mathrm{ml}$ sample and followed the Lizada and Yang method (1979) with the modifications of Makhlouf et al. (1989). Analyses were performed in triplicate.

Florets were selected for the measurement of sepal chlorophyll content with or without the removal of pistil and stamens. The sepals of the florets to be dissected were gently teased apart under a dissecting microscope, and the pistil and stamens were removed using a sharp, sterilized scalpel. After 3 days in ethylene-free air, the sepals of intact and dissected florets were removed and chlorophyll content was analyzed.

Data analyses. The SAS program (Cary, N.C.) was used for statistical analyses; these included analysis of variance, means and SE, least significant difference of multiple comparison and linear regression. All experiments were repeated at least twice.

\section{Results}

Degreening in response to propylene. Hue angle was highly correlated $\left(r^{2}=0.95, \mathrm{n}=12\right)$ with total chlorophyll content of broccoli florets. Both hue angle and chlorophyll content declined as the florets began to yellow when held at $20 \mathrm{C}$ in darkness. Since the measurement of chlorophyll content in plant tissues is a destructive process, hue-angle change has been used as measure of degreening in this work.

Florets attached to broccoli heads began to degreen immediately after harvest, with a large decline in hue angle between 48 and

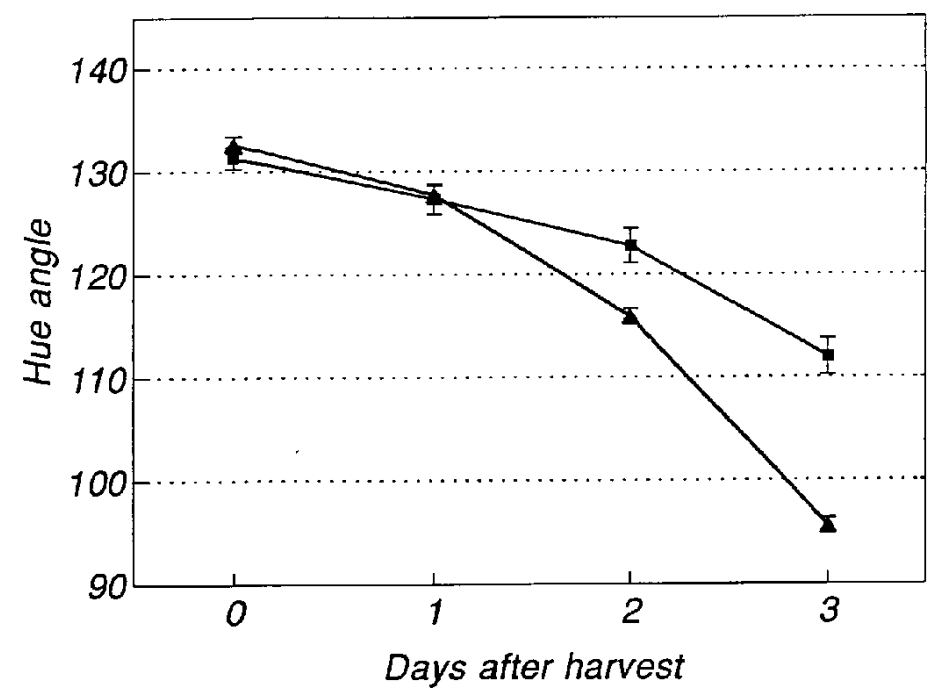

Fig. 1. Color changes of florets of harvested broccoli heads exposed to propylene at $20 \mathrm{C}$ in the dark for up to $72 \mathrm{~h}$. In this and subsequent figures, bars are SE; ( $\mathbf{\square})$ air, (А) $0.5 \%$ propylene. 
$72 \mathrm{~h}$ (Fig. 1), during which time the florets yellowed. Continuous postharvest exposure to $0.5 \%$ propylene enhanced the rate of hueangle decline after $24 \mathrm{~h}$ of treatment. There was no difference between propylene-treated and air-treated broccoli over the first $24 \mathrm{~h}$ after harvest.

After 3 days at 20C in darkness, chlorophyll was lost from the control florets (Table 1). Propylene treatment induced a greater loss of floret chlorophyll.

Respiration and ethylene production after propylene treatment. The respiration rate of broccoli heads held in air declined

Table 1. Chlorophyll content of florets of harvested broccoli heads treated with propylene $(0.5 \%)$ for 3 days at $20 \mathrm{C}$ in the dark.

\begin{tabular}{lcc}
$\begin{array}{l}\text { Days at 20C } \\
\text { in the dark }\end{array}$ & Treatment & $\begin{array}{r}\text { chlorophyll } \\
\left(\mu \mathrm{g} \cdot \mathrm{g}^{-1}\right)\end{array}$ \\
\hline 0 & & $908 \mathrm{a}$ \\
3 & In air & $305 \mathrm{~b}$ \\
3 & ${\text { In } \mathrm{C}_{3} \mathrm{H}_{6}}_{90 \mathrm{c}}$
\end{tabular}

All values are means, and all are significantly different at $P \leq 0.05$ by LSD. rapidly during the first $24 \mathrm{~h}$ after harvest to $\approx 30 \%$ of the initial rate (Fig. 2a). A similar, although smaller, decline in respiration occurred in branchlets (Fig. 2b). In heads and branchlets, the respiration rate gradually increased from 24 to $72 \mathrm{~h}$ as the florets yellowed.

Ethylene synthesis from heads and branchlets held in air was low ( $<1 \mathrm{nl} \mathrm{C}_{2} \mathrm{H}_{4} / \mathrm{g}$ per h) (Fig. $2 \mathrm{c}$ and d), but levels increased for both heads and branchlets during the 72-h experiment.

Exposure to $0.5 \%$ propylene from harvest significantly depressed respiration in heads after $8 \mathrm{~h}$ (Fig. 2a), but then stimulated the respiration rate relative to tissues held in air. A similar propylene-induced increase in respiration occurred in branchlets $36 \mathrm{~h}$ after the treatment began (Fig. 2b). Ethylene synthesis was also stimulated by added propylene (Fig. $2 \mathrm{c}$ and d). This occurred earlier in branchlets than in heads.

Sensitivity to ethylene or propylene. Broccoli branchlets were exposed continuously for $36 \mathrm{~h}$ to ethylene at various concentrations and the response, as change in hue angle, was measured (Fig. 3 ). The response to added ethylene was proportional to the ethylene concentration at low doses $(0.01$ and $0.1 \mathrm{ppm})$ and became saturated at $1.0 \mathrm{ppm}$ for the exposure time used in this study.

To study more closely the change in sensitivity of broccoli
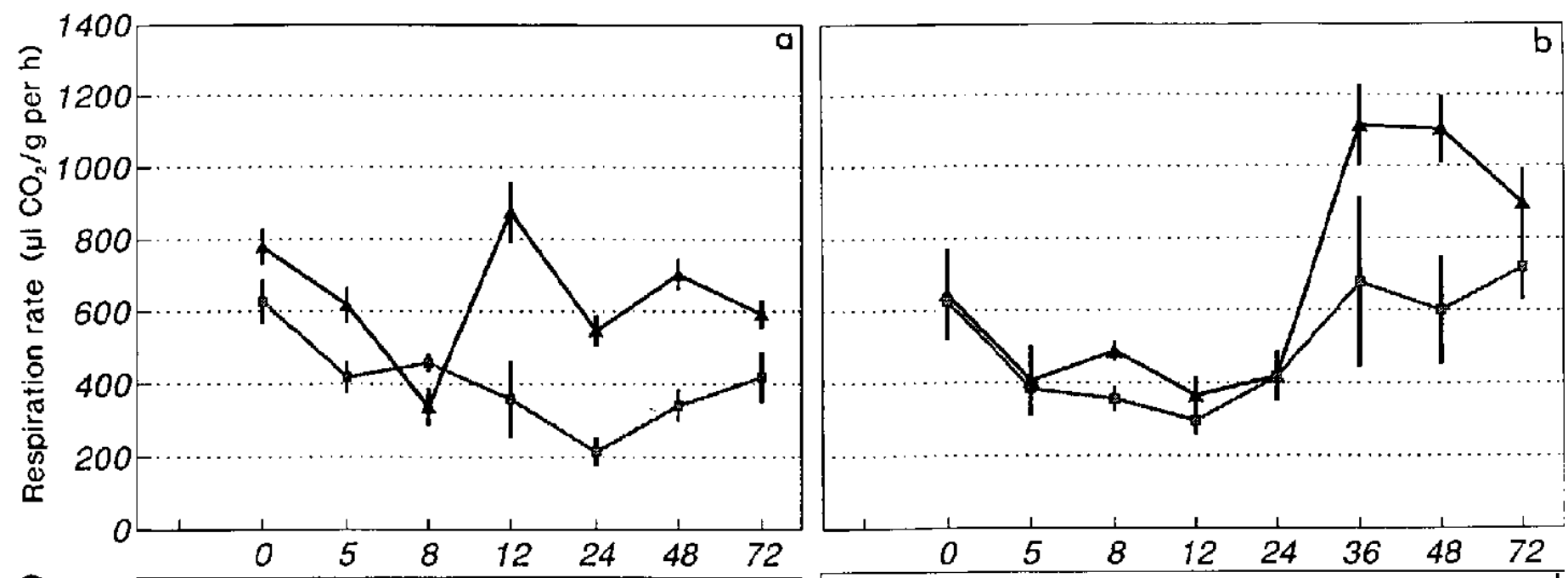

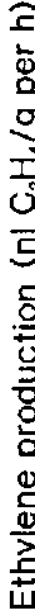
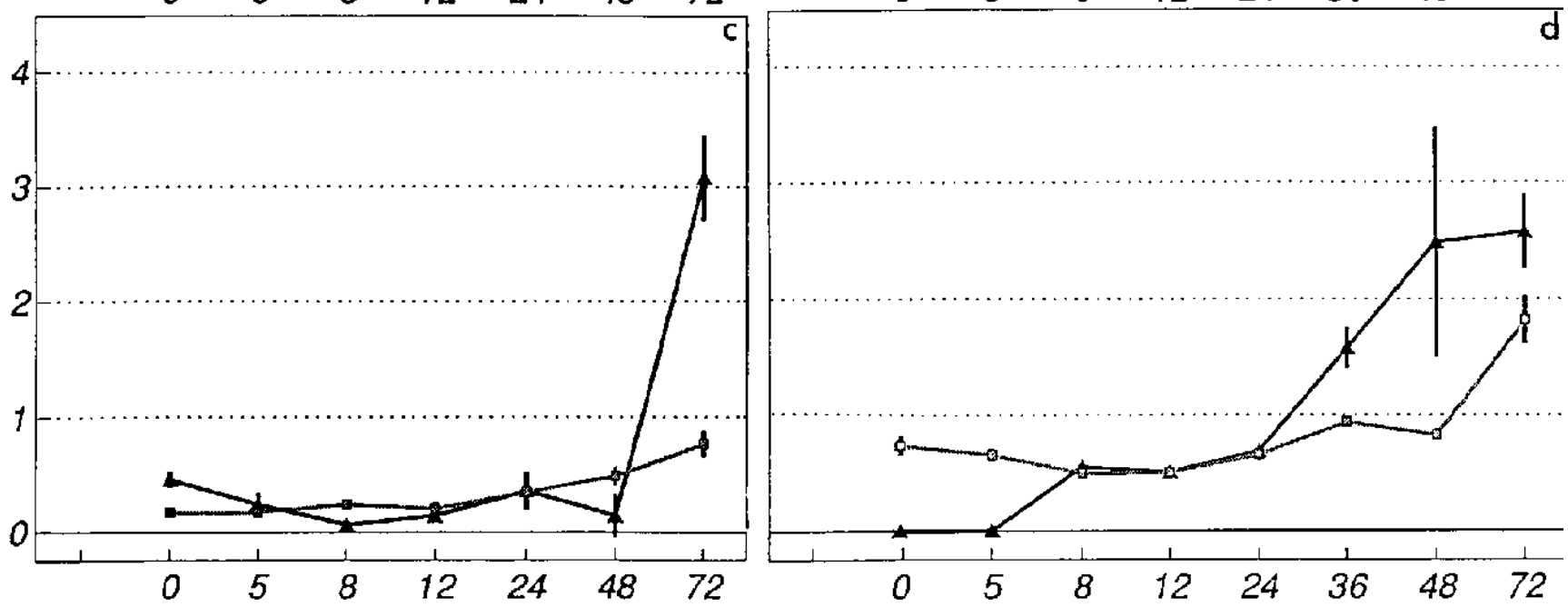

Time (h) after harvest

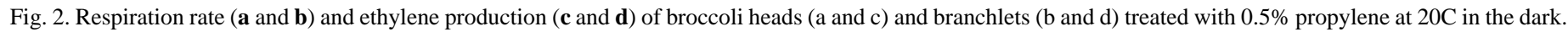
) air, (A) $0.5 \%$ propylene. 


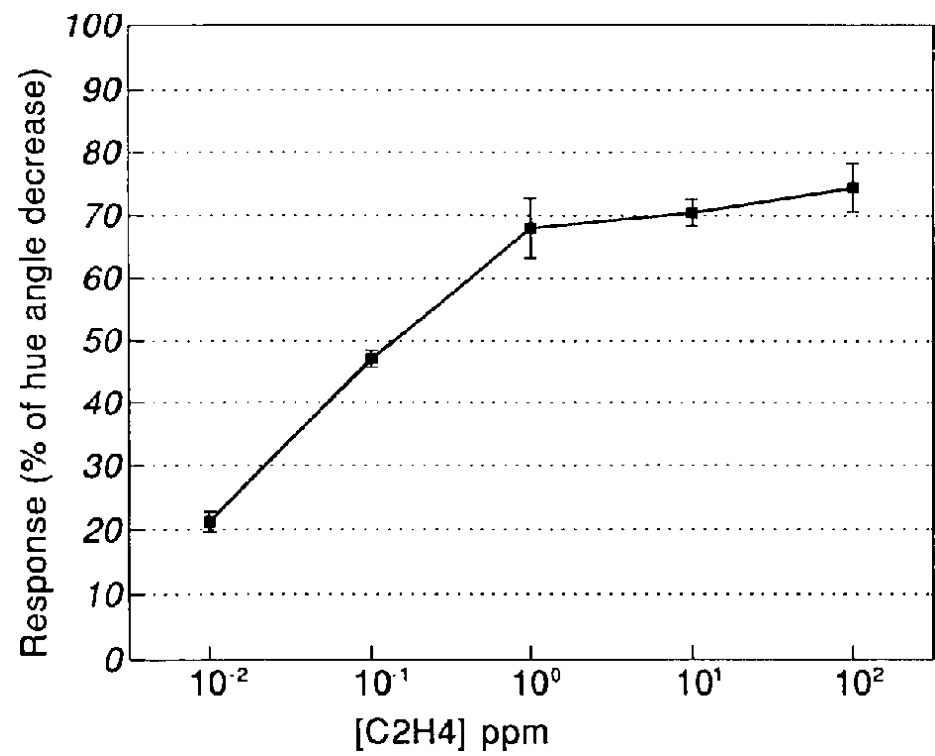

Fig. 3. Dose-response curve showing color change of florets of broccoli branchlets in response to applied ethylene for $36 \mathrm{~h}$ at $20 \mathrm{C}$ in the dark, and the percentage hueangle decrease subsequently determined.

tissues to ethylene, branchlets were harvested and held in darkness at $20 \mathrm{C}$ for $0,24,48$, and $72 \mathrm{~h}$ before exposure to $0.5 \%$ propylene (Fig. 4). The florets of branchlets (Fig. 4a) and those attached to whole heads (Fig.1) showed a similar pattern of hue-angle decline in air, with the same rapid decline in hue angle seen between 48 and $72 \mathrm{~h}$. Propylene treatment also accelerated yellowing in branchlets.

Exposure to propylene from harvest ( 0 h, Fig. 4 a) did not induce a decrease in hue angle until $36 \mathrm{~h}$. Propylene treatment beginning $24 \mathrm{~h}$ after harvest (Fig. 4b) produced a similar response to a treatment beginning at $0 \mathrm{~h}$, although the response was obvious 24 $\mathrm{h}$ after the treatment started. After a 48-h delay in air before propylene exposure (Fig. 4c), a significant response occurred just $12 \mathrm{~h}$ after the treatment began, but the rate of degreening due to propylene began to decline. When propylene treatment was delayed for $72 \mathrm{~h}$ after harvest, no difference of response was seen compared with branchlets held in air.

Ethylene, ACC content, and ACC oxidase in whole and dissected florets. Ethylene production from individual florets increased $48 \mathrm{~h}$ after harvest and at the third day was 3-fold higher than the initial rate (Fig. 5a). Ethylene production from the dissected parts of individual florets followed different patterns. Sepal ethylene production declined during the first $24 \mathrm{~h}$ and then remained low. Petal ethylene was not measurable initially, increased only slightly at 24 and $48 \mathrm{~h}$, and then was undetectable again at 72 h. Stamen ethylene production increased at $48 \mathrm{~h}, 24 \mathrm{~h}$ earlier than the increase in the pistil and intact florets. At $72 \mathrm{~h}$, the pistil and intact florets produced similar amounts of ethylene (13 to $15 \mathrm{nl}$ $\mathrm{C}_{2} \mathrm{H}_{4}$ /g per h).

ACC oxidase activity also varied in different organs of the floret (Fig. 5b). Activity in all parts was very low initially, but in stamens it increased substantially at $24 \mathrm{~h}$; this was $24 \mathrm{~h}$ before any increase in activity was seen in the pistil. At $48 \mathrm{~h}$ there was a dramatic increase in pistil ACC oxidase activity. Only small increases in petal, sepal, and intact floret tissues occurred at $48 \mathrm{~h}$, and at this time ACC oxidase activity in pistil and stamens was seven times higher than in the other parts of the floret.

At harvest, the ACC content in dissected petals was higher than in other floret parts (Fig. 5c), but declined rapidly during the first $24 \mathrm{~h}$. The ACC content of petals and sepals was $30 \%$ to $50 \%$ of the
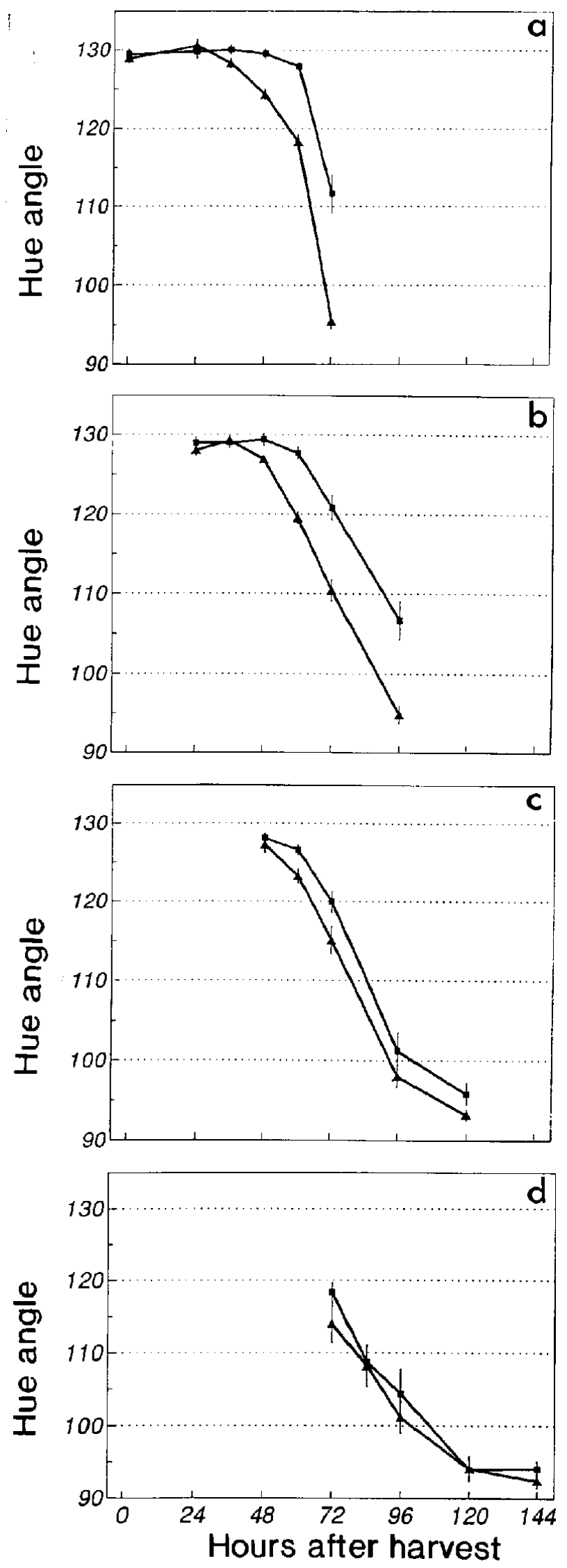

Fig. 4. Effect of propylene applied at various times after harvest on color change of florets of broccoli branchlets held at $20 \mathrm{C}$ in the dark. Branchlets were excised from heads at harvest and held for 0 (a), 24 (b), 48 (c), or 72 (d) h in air after excision before exposing to propylene for an additional $72 \mathrm{~h}$. See legend to Fig.1. 

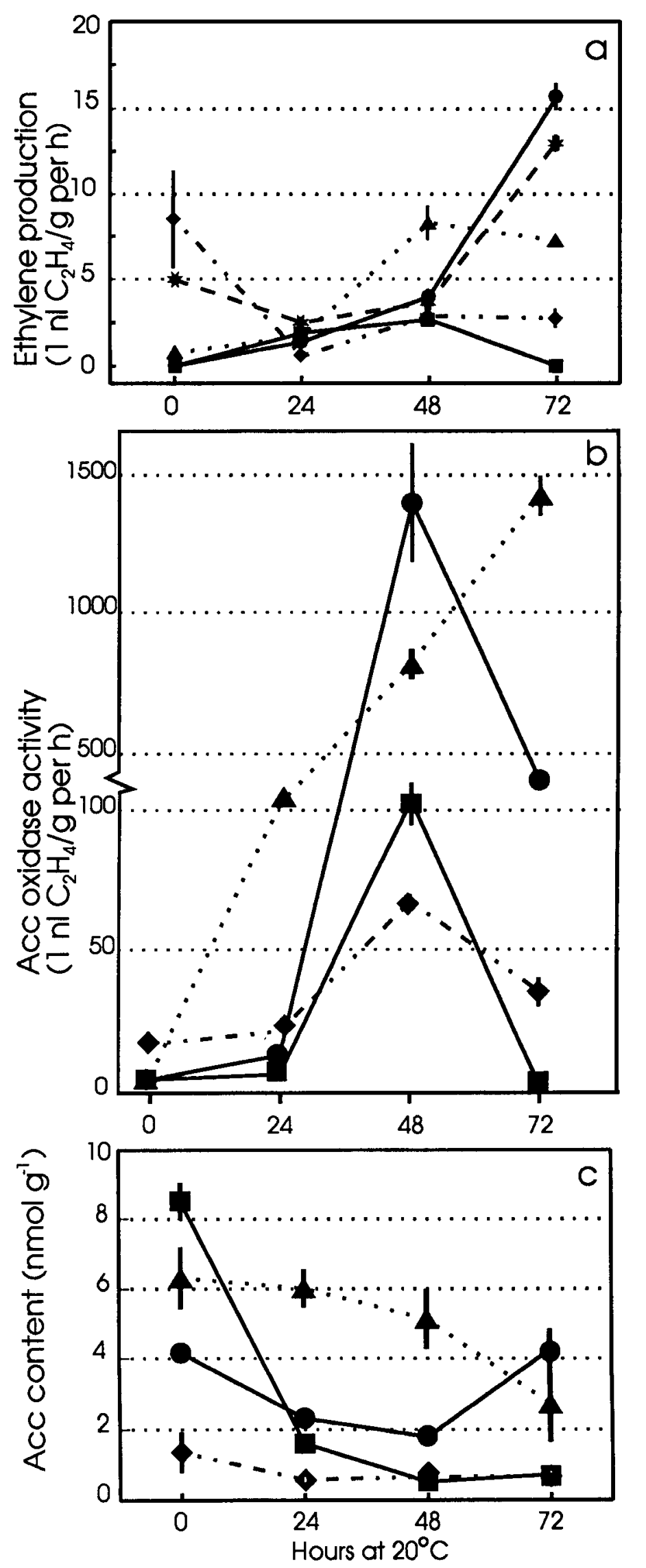

Fig. 5. Ethylene production, activity of ACC oxidase, and ACC contents in the parts of large broccoli florets at $20 \mathrm{C}$ in the dark. Where error bars are not shown they are covered by the symbol. (*) floret; $(\bullet)$ sepal; $(\boldsymbol{\square})$ petal; $(\boldsymbol{\Delta})$ stamen; $(\boldsymbol{O})$ pistil.
Table 2. Chlorophyll content of broccoli sepals from florets with or without stamens and pistils.

\begin{tabular}{lcc}
\hline \hline Days at 20C & $\begin{array}{c}\text { Floret } \\
\text { treatment }\end{array}$ & $\begin{array}{c}\text { Total } \\
\text { chlorophyll } \\
\left(\mu \mathrm{g} \cdot \mathrm{g}^{-1}\right)\end{array}$ \\
\hline 0 & Intact & $677.9 \mathrm{a}$ \\
3 & Intact & $237.7 \mathrm{c}$ \\
3 & Without stamens & $331.0 \mathrm{~b}$ \\
& and pistils &
\end{tabular}

Values are the means $(\mathrm{n}=3)$. Mean separation within columns at $P \leq 0.05$ by LSD. Chlorophyll content is based on the mass of sepals after dissection.

levels found in the pistil and stamen for the rest of the time.

Chlorophyll content of dissected florets. The chlorophyll content of sepals from individual florets held 3 days either with or without pistil and stamens was measured (Table 2). In intact florets, the total chlorophyll content of sepals declined $65 \%$ over 3 days, whereas when pistil and stamens were removed total chlorophyll in sepals declined by only $50 \%$.

\section{Discussion}

The role that ethylene plays in the yellowing of broccoli tissues after harvest has led our research into two main areas. First, if endogenous ethylene production is important, information is needed on which tissues produce ethylene and at which times. Second, the tissue's ability to sense and respond to the hormone may significantly influence the yellowing process.

Makhlouf et al. (1989) indicated that broccoli can be classified as climacteric since florets became yellow as respiration and ethylene production increased. In this work with 'Shogun', whole heads and branchlets held in air produced only low ethylene levels, whereas florets (free of the fleshy stem tissues) produced significantly more ethylene, and the ethylene levels increased as the tissues yellowed. These results agree with those of Makhlouf et al. (1989) and those of Aharoni et al. (1985) who demonstrated that florets produce significantly more ethylene than whole heads of broccoli. It seems that the physiological activity of florets is being diluted and perhaps masked by the other tissues in an intact head. 'Shogun's response to propylene provides further evidence of its climacteric status. Propylene treatment induced a sustained stimulation of respiratory activity, an increase in ethylene synthesis, and a yellowing acceleration. These responses typify climacteric rather than non-climacteric systems (Biale and Young, 1981).

These findings led us to focus on the physiological changes occurring within an individual floret. A broccoli floret is an immature flower with developing reproductive and vegetative structures, which harvest stress forces into premature senescence. In a mature carnation, different parts of the flower produce different ethylene amounts during senescesce (Nichols, 1977; Nichols et al., 1983; Woodson, 1987). In unpollinated flowers, ethylene synthesis may occur simultaneously in all the floral organs. After pollination, however, there is a rapid induction of ethylene synthesis in the style, followed a few hours later by greater ethylene synthesis in the petals, leading to premature senescence (Nichols, 1977). In this situation, Nichols et al. (1983) proposed that ACC was transmitted from the stigma to the petals, resulting in greater ethylene production. It is also possible that ethylene itself can move through the connecting flower tissues to induce autocatalytic ethylene production (Woodson, 1987). A variety of other of signals, including wounding, auxin, water loss, oxygen, and carbon dioxide levels, can also influence ethylene synthesis and 
action (Yang, 1985). These may also affect the involvement of ethylene in broccoli yellowing.

In broccoli, the reproductive structures clearly influence the rate of yellowing in sepals, since removal of the pistil and stamens significantly reduces the rate of sepal yellowing. Florets and stems assembled as branchlets or in heads typically show greatest sepal yellowing between 2 and 3 days after harvest. This loss of chlorophyll probably occurs as a result of earlier processes. Just 1 day after harvest, ACC oxidase activity was higher in stamens than in any other floret tissue, and by the second day, ACC oxidase activity in stamens and the pistil were $>7$-fold higher than in other tissues. This greater enzyme activity is also reflected in higher levels of ethylene production in these structures as sepal yellowing develops.

The patterns of change in ACC content in the pistil and stamens are closely related to probable use in the ACC oxidase reaction. Further research is required to determine the nature of the signal influencing chlorophyll loss from sepals. The sepals themselves produce only low levels of ethylene 1 to 3 days after harvest. Perhaps yellowing is mediated by a change in the sensitivity of sepal tissue to the ethylene that is being produced by the reproductive structures in the floret.

The ability of plant tissues to respond to a hormone signal may depend on the maturity or number of receptor molecules or the integrity of the signal transduction pathway (Sisler and Wood, 1987; Woodson, 1991; Yang, 1985, 1987). Preclimacteric carnation flowers exposed to ethylene will induce autocatalytic ethylene production and have premature petal senescence (Borochov and Woodson, 1989). Immature green tomatoes and apples will ripen only in response to exogenous ethylene after ontogeny has proceeded to the point at which the tissues become receptive (McGlasson et al., 1975). Although it has been shown that ethylene will accelerate broccoli degreening, no research has examined changes in sensitivity of broccoli tissues to ethylene.

Our research demonstrates that broccoli is sensitive to exogenous ethylene; however, exposure to propylene does not induce an immediate response. Delays of between 24 and $72 \mathrm{~h}$ occurred between exposure to propylene after harvest and a stimulation of respiration and ethylene production. A delay also occurred between propylene exposure and a color response. The color of broccoli branchlets held in propylene immediately after harvest was the same as that of branchlets held in air when measured after $24 \mathrm{~h}$. This suggests that either the broccoli tissues are not sensitive to propylene during this time, or that it takes at least $24 \mathrm{~h}$ from signal reception before a physiological response will occur. When tissues were aged for $24 \mathrm{~h}$ in air before propylene treatment, the color response was almost identical to tissues treated with propylene immediately after harvest. This does not suggest that tissues cannot respond within $24 \mathrm{~h}$ of signal perception, but rather that the florets only become sensitive to propylene at $24 \mathrm{~h}$ after harvest. The reduced response in tissues aged 48 and $72 \mathrm{~h}$ before propylene treatment indicates a reduction in sensitivity (i.e., ethylene receptors are already saturated by internal ethylene) or a reduced ability to respond (i.e., the tissues are already yellowing before propylene exposure).

The sensitivity of flower tissues to ethylene increases with age, with more mature petals senescing in response to lower ethylene concentrations (Borochov and Woodson, 1989). It is possible that other hormones in petal tissues will regulate sensitivity to ethylene, and that the balance of senescence inhibitors and senescence promoters (e.g., ethylene) regulates this response (Woodson, 1991). Broccoli florets treated with cytokinin (benzyladenine) remain greener and have a longer shelf life than untreated tissues (Rushing, 1990). Perhaps changes in phytohormone balance, cytokinins, and ethylene, for example, could influence the sensitivity of broccoli tissues to ethylene. Research is continuing to test these hypotheses.

\section{Literature Cited}

Aharoni, N., S. Philosoph-Hadas, and R. Barkai-Golan. 1985. Modified atmospheres to delay senescence and decay of broccoli. Proc. 4th Natl. Controlled Atmosphere Conf. Dept. of Hort. Sci., Raleigh, N.C. Hort. Rpt. 126:169-177.

Biale, J.B. and R.E. Young. 1981. Respiration and ripening in fruit-retrospect and prospect, p.1-39. In: J. Friend and M.J.C. Rhodes (eds.). Recent advances in the biochemistry of fruits and vegetables,. Academic Press, London.

Borochov, A. and W.R. Woodson. 1989. Physiology and biochemistry of flower petal senescence. Hortic. Rev. 11:15-43.

Firn, R.D. 1986. Growth substance sensitivity: The need for clearer ideas, precise terms and purposeful experiments. Physiol. Plant. 67:267-272.

Huber, D.J. 1987. Postharvest senescence: An introduction to the symposium. HortScience 22:853-854

Lizada, M.C.C. and S.F. Yang. 1979. A simple and sensitive assay for 1-aminocyclopropane-1-carboxylic acid. Anal. Biochem. 100:140-143.

Makhlouf, J., C. Willemot, J. Arul, F. Castaigne, and J. Emond. 1989. Regulation of ethylene biosynthesis in broccoli flower buds in controlled atmospheres. J. Amer. Soc. Hort. Sci. 114:955-958.

Makhlouf, J., C. Willemot, J. Arul, F. Castaigne, and A. Gosselin. 1991. Le role de I ethylene dans la conservation et la regulation de la biosynthese de I'ethylene des florets de brocoli apres recolte. Effec de la temperature. Can. Inst. Sci. Technol. J. 24:42-47.

Moran, R. and D. Porath. 1980. Chlorophyll determination in intact tissues using $N, N$-dimethylformamide. Plant Physiol. 65:478-479.

McGlasson W.B., H.C. Dostal, and E.C. Tigchelaar. 1975. Comparison of propylene-induced responses of immature fruit of normal and mutant tomatoes. Plant Physiol. 85:218-222.

Nichols, R. 1977. Sites of ethylene production in the pollinated and unpollinated senescing carnation (Dianthus caryophyllus) inflorescence. Planta 135:155-159.

Nichols, R., G. Bufler, Y. More, D.W. Fujino, and M.S. Reid. 1983. Changes in ethylene production and 1-aminocyclopropane-1-carboxylic acid content of pollinated carnation flowers. J. Plant Growth Regulat. 2:1-8.

Rushing, J.W. 1990. Cytokinins affect respiration, ethylene production, and chlorophyllretention of packaged broccoli florets. HortScience 25:88-90.

Sisler, E.C. and C. Wood. 1987. Ethylene binding and evidence that binding in vivo and in vitro is to the physiological receptor, p. 239-248. In: D. Klambt (ed.). Plant hormone receptors. NATO ASI series. vol. H10. Spring-Verlag, Berlin.

Wang, C.Y. 1977. Effect of aminoethoxy analog of rhizobitoxine and sodium benzoate on senescence of broccoli. HortScience 12:54-56.

Watada, A.E. 1986. Effects of ethylene on the quality of fruits and vegetables. Food Technol. 40:82-85.

Woodson, W.R. 1987. Changes in protein and mRNA populations during the senescence of carnation petals. Physiol. Plant. 71:495-502.

Woodson, W.R. 1991. Gene expression and flower senescence. In: Harding, J., F. Singh,. and Mol, J.N.M. (eds.). Genetics and breeding of ornamental species. Kluwer Academic Publishers, Boston.

Yang, C.Y. 1985. Biosynthesis and action of ethylene. HortScience 20:41-45.

Yang, C.Y. 1987. Regulation of biosynthesis and action of ethylene. Acta Hort. 210:53-59. 